\title{
PERCOBAAN PEMBUNUHAN \\ SEBAGAI PENGHALANG HAK WARIS \\ PERSPEKTIF HUKUM ISLAM DAN KOMPILASI HUKUM ISLAM
}

\author{
Akhmad Khisni, M. Ulinnuha \\ Dosen Fakultas Hukum UNISSULA \\ Email : akhmadkhisniunissula@gmail.com
}

\begin{abstract}
In terms of the obstruction of the right of inheritance for the crime of attempted murder of a conflict between Islamic Law and Islamic Law Compilation (KHI). In Islamic law, which was the cause of obstruction of the right of inheritance is someone for murder, slavery, religious differences, and different countries. In conditions that are not elements of the crime of attempted murder as the cause of obstruction of an inheritance. This provision departs from the principle of law in Islamic law regarding jarimah completed the murder and no jarimah / pending (attempted murder).

On the other hand, clearly states KHI jarimah attempted murder is the element that causes obstruction of the right of inheritance as a provision contained in Article $173 \mathrm{KHI}$. Thus visible difference between the provisions of Islamic law and $\mathrm{KHI}$, which has been placed as the provisions of Islamic law for the people of Indonesia.

To address the problem, the authors use the research methods of law with juridicalnormative legal research conducted by prioritizing research library materials or documents referred to secondary data, in the form of legal materials, primary and secondary. Specifications research is descriptive, which aims to give an overview conducted by way of qualitative theories of law and legal doctrine, and expert opinion of Islamic law.

In conclusion, between Islamic law and there is no difference $\mathrm{KHI}$ opposite each other with respect to the legal principles adopted by each. The provisions in Article $173 \mathrm{KHI}$ can be filed as a realization of the principles of Islamic law in the delivery of a legal provision will be enforced to have known it, or judge to determine the sentence for the crime ta'zir (jarimah). Conditions resulting known it, or judge it to be established in the form of a regulatory law that was born because of judicial decisions (jurisprudence), which in this case is the provision of an obstruction of the right of inheritance for reasons of criminal offenses of attempted murder.
\end{abstract}

Keywords: Attempted Murder, prevention Inheritance Rights, Islamic Law, Islamic Law Compilation

\begin{abstract}
Abstrak
Dalam ketentuan tentang terhalangnya hak kewarisan karena tindak pidana percobaan pembunuhan terdapat perbedaan antara Hukum Islam dan Kompilasi Hukum Islam (KHI). Dalam Hukum Islam, yang menjadi sebab terhalangnya hak kewarisan seseorang adalah karena pembunuhan, perbudakan, perbedaan agama, dan berbeda negara. Dalam ketentuan itu tidak terdapat unsur tindak pidana percobaan pembunuhan sebagai sebab terhalangnya hak waris seseorang. Ketentuan ini berangkat dari prinsip hukum dalam Hukum Islam mengenai jarimah yang telah selesai yaitu pembunuhan dan jarimah yang tidak/belum selesai (percobaan pembunuhan).

Di sisi lain, $\mathrm{KHI}$ secara jelas menyatakan jarimah percobaan pembunuhan merupakan unsur yang menyebabkan terhalangnya hak waris seseorang sebagaimana terdapat dalam ketentuan Pasal $173 \mathrm{KHI}$. Dengan demikian terlihat perbedaan antara ketentuan yang diatur
\end{abstract}


dalam Hukum Islam dan $\mathrm{KHI}$, yang selama ini ditempatkan sebagai ketentuan Hukum Islam untuk masyarakat Indonesia.

Untuk menjawab permasalahan, penulis menggunakan penelitian hukum dengan metode pendekatan yuridis-normatif, yaitu penelitian hukum yang dilakukan dengan mengutamakan meneliti bahan pustaka atau dokumen yang disebut data sekunder, berupa bahan-bahan hukum primer dan sekunder. Spesifikasi penelitian adalah deskriptif analitis, yang bertujuan memberi gambaran yang dilakukan dengan menggunakan cara kualitatif dari teori-teori hukum dan doktrin hukum serta pendapat pakar hukum Islam.

Dari hasil penelitian dapat disimpulkan, antara Hukum Islam dan $\mathrm{KHI}$ tidak terdapat perbedaan yang bertentangan antara satu dengan lainnya terkait dengan prinsip hukum yang dianut oleh masing-masingnya. Ketentuan dalam Pasal $173 \mathrm{KHI}$ ini bisa diajukan sebagai realisasi dari prinsip dalam Hukum Islam tentang diserahkannya sebuah ketentuan hukum yang akan diberlakukan kepada ulil amri atau hakim dalam menentukan hukuman ta'zir atas tindakan pidana (jarimah). Ketentuan yang dihasilkan ulil amri atau hakim itu diwujudkan kepada suatu peraturan dalam bentuk pasal hukum yang lahir karena keputusan peradilan (yurisprudensi), yang dalam hal ini adalah ketentuan pasal tentang terhalangnya hak kewarisan seseorang karena alasan tindak pidana percobaan pembunuhan.

Kata kunci: Percobaan Pembunuhan, Penghalang Hak Waris, Hukum Islam, Kompilasi Hukum Islam

\section{A. Latar Belakang Masalah}

Salah satu hal yang diatur dalam ketentuan yang berhubungan dengan meninggalnya seseorang adalah mengenai harta kekayaaan dari orang yang meninggal itu kepada pihak-pihak lain yang masih hidup, atau beralihnya status kepemilikan atas harta benda bersangkutan kepada orang atau pihak-pihak yang ditetapkan sebagai ahli waris atau pihak penerima. Ketentuan yang mengatur mengenai proses ini diatur dalam ketentuan Hukum Waris, ${ }^{1}$ di mana hampir semua jenis produk hukum yang berlaku dan diterapkan di berabagi belahan dunia telah mengaturnya, termasuk dalam Hukum Islam.

Dalam Hukum Islam yang produk hukum yang di dalamnya mengatur mengenai ketentuanketentuan mengenai waris ini dinamakan Faraid. Salah satu dasar tentang keberadaan dari Faraid ini adalah sebagaimana diungkapkan dalam hadits Rasulullah Saw: "Bagikanlah pusaka bagi yang berhak menerimanya. Maka suatu pusaka yang masih tersisa untuk laki-laki yang lebih dekat (hubungan kekeluargaannya) dengan mayit." 1 Suparman Usman, 1993, Ikhtisar Hukum Waris menurut KUHP, Dar al Ulum Press, tt., h. 49-50.

2 Imam al-Bukhari, 1971/1401 H, Shahih al-Bukhari, Juz 8, Dar al-Fikr, Beirut Hadits Riwayat Bukhari dari Ibnu Abbas.
Peralihan harta benda milik orang yang telah meninggal dunia kepada mereka yang masih hidup, atau orang-orang yang secara huku atau ditetapkan sebagai pihak penerima harta benda bersangkutan itu tidak menutup kemungkinan adanya berbagai persyaratan terjadinya kewarisan. Persyaratan-persyaratan itu di antaranya adalah yang berkaitan dengan pewaris atau persyaratan yang berhubungan dengan pihak pewarisnya.

Secara sederhana dapat dinyatakan, bahwa syarat-syarat bagi pewaris adalah orang yang meninggalkan harta benda sebagai warisan itu benar-benar telah meninggal dunia. Dari sini kemudian pengembangan pembahasan, bahwa apakah yang meninggalkan warisan itu meninggal secara hakiki atau meninggal secara yuridis. ${ }^{3}$

Meninggal atau wafat secara hakiki adalah meninggalnya seseorang yag di dalamnya tanpa harus melalui pembuktian yang dapat diketahui dan dinyatakan bahwa seseorang telah meninggal dunia. Sementara meninggal dunia secara yuridis (hukmi) diartikan sebagai seseorang yang dinyatakan telah meninggalkan dunia secara yuridis (hukum) dengan berdasar

3 Ahmad Rofiq, 1993, Fiqih Mawaris, RajaGrafindo Persada, Jakarta, h. 22. 
kepada keputusan yang dinyatakan oleh lembaga hukum yang berwenang. Untuk contoh kasus dari pengertian yan terakhir ini adalah, misalnya pada kasus hilangnya seseorang yang tidak diketahui dimana dan bagaimana keberadaannya. Istilah untuk jenis kematian seperti ini adalah Mati Takdiri, yaitu anggapan bahwa seseorang telah meninggal dunia.

Kembali kepada pembahasan tentang kewarisan. Dalam ketentuan yang diatur oleh Hukum Islam dinyatakan, sebab-sebab menerima warisan di antaranya dikarenakan adanya hubungan kekerabatan atau hubungan darah antara pihak yang meninggal dengan orangorang yang ditinggal mati, karena hubungan perkawinan, dan karena memerdekakan hamba (wala'). ${ }^{4}$ Selain itu orang atau pihak yang berhak menerima harta peninggalan juga harus sudah ada atau masih hidup pada saat masa kematian dari orang/pihak yang meninggalkan warisan. Pengertian hidup ini juga dapat diartikan hidup secara nyata maupun hidup secara hukmi (yuridis). Pengertian hidup secara yuridis adalah keadaan seseorang yang tidak diketahui keberadaannya namun berdasarkan ketetapan hukum masih dinyatakan sebagai hidup. Orang tersebut juga tidak diketahui apakah masih hidup atau pengadilan sebelum keluarnya keputusan hukum dari pengadilan yang menyatakan tentang meninggalnya.

Selain persyaratan meninggalnya yang meninggalkan warisan dan masih hidupnya para ahli waris, persyaratan untuk mendaparkan pewarisan adalah disebabkan karena tidak adanya sebab-sebab atau hal-hal yang menghalangi pihak ahli waris untuk menerima warisan.

Dalam Hukum Islam, yang menjadi sebab atas terhalang menerima warisan juga telah diatur. Terdapat empat hal yang menjadi sebab atas terhalang seseorang dalam menerima warisan yaitu: pembunuhan, perbedaan agama, perbudakan, dan murtad. Sementara dalam ketentuan produk hukum yang lain, misalnya dalam KUHPerdata pada Bab XII Pasal 838, dinyatakan bahwa yang tidak patut menjadi ahli waris dan karenanya pun dikecualikan dari pewarisan adalah: 1) pihak yang dihukum karena dipersalahkan telah membunuh atau melakukan percobaan 4 Suparman Usman, Ikhtisar Hukum Waris...., h. 41. pembunuhan terhadap pihak yang meninggal, 2) pihak yang dengan keputusan hakim/pengadilan dipersalahkan karena secara menfitnah telah mengajukan pengaduan terhadap pihak yang meninggal dunia dimana pengaduan tersebut mengenai hal bahwa orang yang meninggal itu telah melakukan kejahatan yang terancam hukuman selama 5 tahun atau yang lebih berat, 3) Mereka/pihak yang melakukan kekerasan atau perbuatan telah mencegah pihak/orang yang meninggal untuk membuat surat wasiat, dan 4) Mereka/pihak yang telah menggelapkan, merusak, atau memalsukan surat wasiat yang dibuat oleh pihak/orang yang meninggal.

Dalam ketentuan hukum lain, yaitu Kompilasi Hukum Islam $(\mathrm{KHI})$ ketentuan mengenai terhalang kewarisan seseorang/pihak juga diatur. Menurut Ikhtiyanto sebagaimana melansir dari Abdurrahman, dinyatakan bahwa Hukum Islam sebagai tatanan hukum yang dipegangi atau ditaati oleh mayoritas rakyat Indonesia merupakan hukum yang telah hidup dalam masyarakat merupakan sebagian dari ajaran dan keyakinan Islam dan ada dalam pembinaan hukum nasional serta merupakan bahan dalam pembinaan dan pengembangannya. ${ }^{5}$

Dalam KHI diungkapkan tentang ketentuan kewarisan ini sebagaimana diuraikan atudalam Buku II yang di dalamnya terdiri atas enam (6) bab dengan 44 pasal. Adapun uraian mengenai ketentuan halangan/terhalangnya kewarisan diungkapkan dalam Pasal 173 yang menjelaskan; seseorang akan terhalang menjadi ahli waris jika dengan keputusan hakim/pengadilan yang memiliki kekuatan hukum yang tetap memutuskan: 1) dipersalahkan telah membunuh atau mencoba membunuh atau menganiaya berat kepada pihak yang meninggalkan warisan/ orang yang meninggal, b) dipersalahkan karena dengan telah mengajukan pengaduan bahwa orang/pihak yang meninggalkan warisan telah melakukan kejahatan yang sanksi hukumnya selama lima (5) tahun penjara atau hukuma yang lebih berat. ${ }^{6}$

Jika melihat pada perumusan dari ketentuan Pasal 173 tersebut muncul kesan $\mathrm{KHI}$ sekedar

5 Abdurahman, 1992, Kompilasi Hukum Islam, Akademika Pressindo, Jakarta, h. 16.

6 Lihat Pasal 173 Kompilasi Hukum Islam (KHI). 
duplikasi (meniru) Pasal 838 KUHPerdata. Tentang hal ini dapat diuraikan, sebagaimana telah diketahui perumusan ketentusan pasal hukum dalam $\mathrm{KHI}$ adalah dengan mengambil dan menempatkan sumber dari AI-Qur'an dan Sunnah sebagai landasan serta sumber utamanya. Dengan menempatkan kedua unsur tersebut dalam menentukan ketentuan yang diaturnya maka sejak semula penyusunan $\mathrm{KHI}$ telah melepaskan diri dari pendapat berbagai mazhab dan pengaruh produk hukum yang lain. Namun begitu meski perumusannya menyandarkan penuh dari AlQur'an dan Sunnah, KHI tetap memerlukan unsur keluwesan yang diusahakan tetap mengacu kepada pemikiran dan pengkajian. ${ }^{7}$

Percobaan pembunuhan sebagai pidana kejahatan, menurut Pasal 53 Kitab KUHP, jelas mempunyai akibat berupa sanksi hukum/pidana. Dalam hubungan antara sanksi hukum yang diatur dalam KUHP dengan masalah kewarisan, dalam nash tidak secara tegas mengaturnya dalam hal sebagai alasan seseorang/pihak ahli waris dalam menerima warisan. Sementara dalam $\mathrm{KHI}$, ketentuan hukum yang mengatur mengenai hal ini diatur pada Pasal 173.

Keadaan ini cukup menarik karena terkesan ada dua pendapat terkait dengan masalah terhalangnya hak kewarisan seseorang/pihak tertentu yang dikarenakan sebelumnya telah terjadi percobaan pembunuhan. Berangkat dari kerangka pemikiran seperti ini maka penyusun mengajukan topik bahasan mengenai kajian ini dengan mengajukan judul "Percobaan Pembunuhan sebagai Penghalang Hak Waris dalam Perspektif Hukum Islam dan KHI".

\section{B. Rumusan Masalah}

Berdasar pada uraian latar belakang di atas dapat diambil rumusan masalah sebagai berikut:

1. Bagaimana perbandingan antara perspektif hukum Islam dan hukum positif dan kompilasi hukum Islam mengenai percobaan pembunuhan?

2. Bagaimana perbandingan antara perspektif hukum Islam dan Kompilasi

7 M. Yahya Harahap, "Materi KHI" dalam Mahfud MD dkk. 1993, Peradilan Agama dan Kompilasi Hukum Islam dala Tata Hukum Indonesia, UII Press, Yogyakarta, h. 69 .
Hukum Islam mengenaipercobaan pembunuhan sebagai penghalang hak waris?

\section{PEMBAHASAN}

A. Perbandingan antara Hukum Islam, Hukum Positif dan KHI tentang Percobaan Pembunuhan

Secara kebahasaan, percobaan diartikan sebagai usaha mencoba sesuatu atau usaha hendak berbuat sesuatu, akan tetapi tidak sampai kepada sesuatu tujuan atau maksud, atau sudah memulai untuk melakukan sesuatu akan tetapi tidak sampai terselesaikan karena suatu sebab. ${ }^{8}$

Istilah 'percobaan' dalam terminologi teknis-yuridis Hukum Islam juga tidak dikenal. Dengan demikian dalam Hukum Islam tidak memberikan ketentuan hukuman yang definitif dalam konsep pidana dalam kategori jarimah percobaan, yang otomatis juga di dalamnya termasuk jarimah percobaan pembunuhan. Dalam teknis yuridis yang terdapat Hukum Islam dan menjadi pembicaraan di kalangan fuqaha adalah tentang pemisahan antara jarimah (pidana) yang telah selesai dan jarimah yang belum selesai. ${ }^{9}$

Ahmad Hanafi mengatakan setidaknya adanya perhatian secara khusus tentang jarimah percobaan ini disebabkan dua unsur yaitu:

a) Percobaan melakukan jarimah tidak dikenakan hukuman had atau qishas, tapi dikenakan hukum ta'zir dengan apapun jenis dari jarimah yang dilakukan itu. Dalam hal ini perhatian fuqaha lebih tertuju pada jarimah hudud dan qishas-diyat dikarenakan unsur dan syarat-syaratnya tetap tanpa mengalami perubahan dan bobot hukuman juga telah ditentukan;

b) Dengan adanya ketentuan yang mencakup dari syara' mengenai

8 R. Sugandi, 1989, KUHP dan Penjelasannya, Usaha Nasional, Jakarta, h. 64.

9 Marsum, 1991, Jinayat: Hukum Pidana Islam, Fakultas Hukum UII, Yogyakarta, h. 151. 
hukuman jarimah ta'zir, maka ketentuan khusus mengenai jarimah percobaan tidak perlu diadakan, sebab jarimah ta'zir dijatuhkan terhadap setiap kesalahan yang tidak dikenakan hukuman had atau kafarat. Artinya, setiap perbuatan yang dianggap salah menurut syara' akan dijatuhi ta'zir selama tidak dikenakan hukuman had atau kafarat. Karena hukuman had atau kafarat hanya dijatuhkan kepada jarimah tertentu yang telah selesai, maka setiap percobaan atas perbuatan yang dilarang oleh hukum (syara') hanya dijatuhi hukuman ta'zir. ${ }^{10}$ Dari uraian di atas kita mendapat pemahaman terhadap alasan mengapa para fuqaha tidak mengadakan pembahasan khusus atas percoban melakukan tindakan kejahatan, karena yang dibutuhkan adalah pemisahan antara jarimah yang telah selesai dan jarimah belum selesai. Sehingga pembahasan tentang relasi antara jarimah yang belum selesai, dalam hal ini jarimah percobaan pembunuhan, kaitannya dengan terhalangnya hak waris maka jelas sekali bahwa ketentuan hukumnya tidak terdapat dalam Hukum Islam.

Ketentuan dalam Hukum Islam mengenai hal yang menjadi penghalang atas hak kewarisan ditetapkan yaitu; pembunuhan, perbudakan, perbedaan agama, dan berbeda negara. Jelas sekali di situ tidak terdapat unsur atau sebab jarimah percobaan pembunuhan sebagai salah satu sebab atas terhalangnya kewarisan seseorang.

Jika dibandingkan dengan produk hukum lainnya, misalnya Hukum Positif, ada perbedaan mengenai ketentuan terhalangnya kewarisan seseorang, khususnya dalam kasus percobaan pembunuhan. Dalam ketentuan yang diatur dalam KUHPerdata di dalamnya ada ketentuan yang mengatur tentang hal 'tidak patut menerima warisan' atau

10 Ahmad Hanafi, 1993, Asas-Asas Hukum Pidana Islam, PT Bulan Bintang, Jakarta, h. 118-119. (onwaardig). Terdapatnya sebab-sebab menurut Undang-undang ahli waris tidak patut atau terlarang (onwaardig) untuk menerima warisan dari si pewaris. ${ }^{11}$ Ahli waris menurut undang-undang yang dinyatakan tidak patut untuk menerima warisan, dalam Pasal 838 KUH Perdata adalah:1) Mereka yang telah dihukum karena dipersalahkan telah membunuh atau mencoba membunuhsi pewaris, 2) Mereka yang dengan putusan hakim pernah dipersalahkan karena secara fitnah telah melakukan pengaduan terhadap si pewaris, ialah suatu pengaduan telah melakukan kegiatan kejahatan yang diancam hukuman penjara lima tahun lamanya atau lebih berat, 3) Mereka yang dengan kekerasan atau perbuatan telah mencegah si pewaris untuk membuat atau mencabut surat wasiat, dan 4) Mereka yang telah menggelapkan, merusak atau memalsukan surat wasiat si pewaris. ${ }^{12}$

Dalam syariat Islam sebuah hukuman itu dijatuhkan dengan otujuan pokok untuk pencegahan, pengajaran, dan pendidikan. Sanksi hukum sebagai sarana untuk pencegahan dalam aplikasinya adalah, bahwa bobot hukuman yang dijatuhkan atau diberikan harus mewujudkan tujuan pencegahan itu yakni tidak boleh kurang atau lebih berat dari ketentuan yang telah digariskan. Dengan demikian jenis hukuman yang dijatuhkan akan menjadi berbeda-beda.

Hal lain yang menjadi salah satu prinsip atas penjatuhan hukuman dalam Hukum Islam adalah tujuan pencegahan. Dengan demikian semua jenis jarimah apapun baik yang terklasifikasi sebagai jarimah yang telah selesai maupun jarimah yang belum selesai baik langsung maupun tidak langsung akan terkena dengan prinsip pemberian pelajaran ini.

Dalam Hukum Islam, jenis dari hukuman itu sendiri terdapat beberapa

11 Suparman Usman, 1993, Ikhtisar Hukum Waris Menurut Kitab Undang-UndangHukum Perdata (Burgerlijk Wetboek), Darul Ulum Press, Serang, h. 58

12 Ibid., h. 60-61. 
macam golongan menurut segi tinjauannya. Dilihat dari segi pertalian atas hukuman dengan lainnya, terdapat empat (4) macam hukuman:

1. Hukuman Pokok (al-uqubah al ashliyah); dio antaranya hukum qishas untuk jarimah pembunuhan dan hukuman potong tangan untuk jariah pencurian.

2. Hukuman Pengganti (al-uqubah badaliyah) yaitu hukuman yang menggantikan hukuman pokok, apabila hukuman pokok tidak dapat dilaksanakan karena alasan yang sah.

3. Hukuman Tambahan (al-uqubah tabi'iyah); yaitu hukuman yang mengikuti hukuman pokok tanpa memerlukan keputusan hakim tersendiri. Seperti misalnya larangan menerima warisan bagi orang yang melakukan pembunuhan terhadap keluarga, sebagai tambahan dari hukuma qishas.

4. Hukuman Pelengkap (al-uqubah takmiliyah); yaitu hukuman yang mengikuti hukuman pokok dengan syarat ada keputusan hakim tersendiri. ${ }^{13}$

Sementara itu jika dilihat dari segi macam atau klasifikasi jarimah yang diancamkan terhadapnya sanoksi hukuman, terdapat empat (4) macam yakni:

1. Hukuman had, yaitu hukuman yang ditetapkan atas jarimah hudud, misalnya berzina, mencuri, dan lainlain.

2. Hukuman qishas-diyat, yaitu hukuman yang ditetapkan atas jarimah qishasdiyat.

3. Hukuman kafarat, yaitu hukuman terhadap sebagian jarimah qishasdiyat dan beberapa jarimah ta'zir, dan

4. Hukuman ta'zir, yaitu hukumanhukuman untuk jarimah-jarimah ta'zir. ${ }^{14}$

13 Ahmad Hanafi, 1993, Asas-Asas Hukum Pidana Islam...., h. 121-123.

14 Marsum, 1984, Jinayat: Hukum Pidana Islam, Fakultas Hukum UII, Yogyakarta, h. 186
Ta'zir sendiri mempunyai pengertian menghinakan pelaku pelaku jarimah karena tindakan pelanggaran hukum dilakukannya itu. Dalam ta'zir, hukuman tidak ditetapkan dengan berdasar ketentuan hukum yang telah ditetapkan (hukum Allah dan Rasul yang termaktub dalam fiqih) sehingga dalam hal ta'zir ini pihak hakim diperkenankan untuk mempertimbangkan bentuk hukuman yang dijatuhkan dan bobot hukumannya. Bentuk hukuman diberikan dengan pertimbangan khusus terhadap berbagai faktor yang mempengaruhi.

Dalam kasus percobaan pembunuhan, maka perbuatan ini akan termasuk dalam kategori dimana dalam hukum Islam? Menurut Islam, jarimah hudud dan qishas yang merupakan jarimah yang selesai maka tidak boleh dipersamakan hukumannya dengan jarimah yang belum selesai. Aturan ini berdasar kepada prinsip hukum dalam hadits Rasulullah Saw; "Siapa yang mencapai hukuman had pada jarimah bukan hudud (yang lengkap) maka ia termasuk orang yang melampaui batas." 15

Aturan tersebut berlaku baik untuk jarimah hudud dan qishas, karena hukuman hudud dan qishas telah ditentukan jumlahnya. ${ }^{16}$ Dengan demikian maka jarimah percobaan pencurian, misalnya, tidak bisa atau tidak boleh dikenakan hukuman dengan potong tangan.

Bahwa hukuman ta'zir dijatuhkan atas setiap perbuatan kesalahan yang tidak dijatuhi hukuman had atau kafarat, karena hukuman ini hanya dijatuhkan terhadap jarimah tertentu yang selesai. Dengan pengertian lain, setiap percobaan (memulai) sesuatu perbuatan yang dilarang hanya dijatuhi hukuman ta'zir. Dengan demikian boleh disimpulkan bahwa pidana yang sesuai dengan ketentuan Hukum Islam terhadap

15 Al-Baihaqi, 1354 H, Assunah al_Kubra Juz 8 Bab Ma Ja-a fi at;Ta'zir, Dar as-Sadir, Beirut, h. 327.

16 Ahmad Hanafi, Asas-Asas Hukum Islam......, h. 125. 
perbuatan percobaan pembunuhan adalah dengan menjatuhkan ta'zir.

Melihat kepada ketentuan yang terdapat dalam Hukum Positif, yaitu KUH Pidana Bab IV Pasal 53 ayat 2 , dinyatakan maksimal pidana yang diancamkan terhadap perbuatan percobaan pembunuhan dikurangi sepertiga. Implisit, ketentuan ini sama dengan ketentuan pidana Islam dalam hal penjatuhan hukuman terhadap tindak pidana percobaan. Dengan begitu, misalnya seorang melakukan pembunuhan (sengaja) dapat dijatuhi hukuman15 tahun penjara sebagaimana termaktub dalam Pasal 838 KUH Pidana, maka untuk pelaku tindakan percobaan pembunuhan, bobot hukuman yang diberikan kepadanya dikurangi sepertiganya yaitu pidana penjara selama 10 tahun.

Namun terdapat kemungkinan lain bahwa sebuah tindak pidana karena tidak memenuhi target tertentu bisa menjadi bentuk pidana tersendiri. Dalam kasus pembunuhan, ketika target yang diharapkan (matinya korban) tidak terpenuhi, maka hal ini menjadi tindak pidana tersendiri yaitu percobaan pembunuhan. Sementara itu dalam percobaan pembunuhan banyak ekses yang ditimbulkan, misalnya, seorang telah melakukan tindakan percobaan pembunuhan dan korban tidak sampai mati tapi mengalami luka-luka pada anggota badannya. Secara niat, pelaku sebenarnya ingin membunuh korban. Secara material kejadian ini dapat dikategorikan jarimah qishas ala ghairi an nafs atau qishas pelukaan (al-jurukh). ${ }^{17}$ Sebagaimana ditegaskan firman Allah Swt. dalam Surat Al-Maidah Ayat 45: "Dan Kami telah tetapkan kepada mereka di dalamnya (at-Taurat) bahwasanya jiwa dibalas jiwa, mata dengan mata, hidung dengan hidung, telinga dengan telinga, gigi dengan gigi, dan luka pun ada qishasnya."

Dengan mengacu pada uraian

17 Marsum, Jinayat: Hukum Pidana Islam....., h. 135. di atas, peran hakim menjadi sangat penting dalam menentukan termasuk tindak pidana apakah suatu perbuatan yang telah dilakukan itu, serta hukuman apa yang paling tepat dijatuhkan kepada pelaku dengan tetap berpedoman pada pertimbangan banyak hal supaya sanksi yang dijatuhkan kepada pelaku tidak melampaui batas atau kurang dari batas yang ditentukan. ${ }^{18}$

Dalam kejadian seperti ini ketentuannya diserahkan kepada ulil amri atau hakim untuk menentukan hukuman ta'zir atas tidakan pidana (jarimah) yang telah dilakukan oleh pihak anak tersebut. Bisa jadi ketentuan hukum terhadap perkara yang demikian itu dituangkan ke dalam suatu peraturan atau regulasi hukum yang khusus atau mungkin hanya diserahkan kepada pertimbangan dari pihak hakim, dalam wujud perundangan yang lahir karena keputusan peradilan (yurisprudensi). ${ }^{19} \mathrm{Hal}$ ini sesuai dengan pernyataan dalam Pasal 229 Kompilasi Hukum Islam (KHI):

"Hakim dalam menyelesaikan perkara-perkara yang diajukan kepadanya, wajib memperhatikan dengan sungguh-sungguh nilai-nilai hukum yang hidup dalam masyarakat, sehingga keputusannya sesuai dengan rasa keadilan."

Dengan bersandar kepada pernyataan pasal di atas, maka dalam hal ini hakim mempunyai tugas dan beban kewajiban untuk memperhatikan dengan sungguhsungguh terhadap nilai hukum yang hidup dalam masyarakat. Hakim harus terus menggali dan menemukan asas-asas dan dasar nilai hukum baru.

Kewarisan adalah salah satu perkara perdata Islam yang ditangani oleh Peradilan Agama dengan berdasarkan hukum Islam yang murni. Hal ini berarti

18 A. Djazuli, 1997, Fiqh Jinayah: Upaya Menanggulangi Kejahatan dalam Islam, PT RajaGrafindo Persada, Jakarta, h. 222.

19 Haliman, 1973, Hukum Pidana Syariat Islam, PT Bulan Bintang, Jakarta, h. 224-225. 
hukum materil yang diterapkan di Peradilan Agama adalah hukum Islam. Mungkin inilah hal yang dimaksud oleh Hakim Agung M. Yahya Harahap bahwa salah satu asas dari Peradilan Agama adalah asas personalitas keislaman. ${ }^{20}$ Maksud dari asas personalitas keislaman tersebut adalah, hanya pemeluk agama Islam sajalah yang menjadi obyek dari pada kekuasaan kehakiman di lingkungan Peradilan Agama.

Perlu juga untuk diuraikan $\mathrm{d}$ sini bahwa ketentuan hukum tentang percobaan pembunuhan yang ternyata tidak menjadi unsur yang secara eksplisit disebutkan sebagai unsur penghalang hak kewarisan seseorang menurut Hukum Islam, nampaknya tidak seharusnya dipahami dalam pemahaman yang bersifat teks semata. Dalam menyikapi ketentuan Hukum Islam, di dalamnya tetap memberi tempat terhadap unsur pemahaman dan pemaknaan yang bersifat dinamis dan kontekstual.

Pemahaman yang dinamis ini adalah, dalam memahami ketentuan yang tertulis dalam Hukum Islam harus menyertakan pemikiran dan pemahaman yang progresif yang tidak terhenti kepada pemahaman yang sama persis dengan ketentuan yang terdapat dalam teks. Jika hal ini yang digunakan maka bisa dimungkinkan pada sebagian besar ketentuan hukum Islam hanya bersifat faktual semata dan akan sulit menunjukkan perspektif aktualitasnya dalam menyikapi perkembangan pemikiran dan zaman.

Demikian halnya dalam memahami ketentuan terhalangnya hak kewarisan karena alasan tindakan percobaan pembunuhan. Memang dalam ketentuan tertulisnya tidak ada atau terdapat ketentuan yang menyatakan bahwa tindakan ini menjadi penghalang terhadap hak kewarisan seseorang.

20 M YahyaHarahap., 1990, Kedudukan, KewenangandanAcaraPeradilan Agama UU No 7 Th 1989, PustakaKartini, Jakarta, h. 137.
Salah satu pintu masuk terhadap dimungkinkannya pidana percobaan pembunuhan sebagai unsur yang bisa menjadi penghalang hak kewarisan Islam adalah pada penerapan hukum ta'zir yang keberadaannya salah satunya ditujukan untuk memberikan sanksi hukum terhadap tindak pidana atau jarimah yang belum selesai. Pertimbangan lainnya yang menurut hemat penulis sangat mendesak adalah bahwa dalam konteks sekarang ini sebagian produk hukum dan kesadaran masyarakat hukum di dunia, termasuk tentunya di Indonesia, sangat mempertimbangkan sekali aspek sosio-yuridis dan aspek HAM. Dalam konteks masyarakat hukum Indonesia, dan juga pada sebagian masyarakat hukum di wilayah-wilayah lain di berbagai belahan dunia, tindak pidana percobaan pembunuhan telah dipahami sekaligus ditempatkan sebagai sebuah tindak pidana mengandung konsekuensi hukum yang tidak ringan, meski bobotnya selamanya tidak akan pernah sama dengan tindakan pembunuhan itu sendiri.

\section{B. Percobaan Pembunuhan sebagai Penghalang Kewarisan dalam KHI}

Dengan dikeluarkannya Inpres Nomor 1 Tahun 1991 tentang Kompilasi Hukum Islam (KHI) yang diperkuat kemudian oleh Keputusan Menteri Agama Nomor 154 Tahun 1991 tentang Pelaksanaan Inpres tersebut, banyak terdapat perkembangan dan penafsiran baru mengenai permasalahan peraturan hukum, khususnya pada Buku Kedua KHI tentang Kewarisan.

Salah satu penafsiran baru yang menarik perhatian perihal beberapa penghalang kewarisan yang tercantum pada Pasal $173 \mathrm{KHI}$. Pasal itu menyebutkan, seseorang terhalang menjadi ahli waris apabila dengan putusan hakim yang telah mempunyai kekuatan hukum yang tetap, dihukum karena:1) Dipersalahkan telah membunuh atau mencoba membunuh atau menganiaya berat pada pewaris, 2) Dipersalahkan secara memfitnah telah mengajukan pengaduan bahwa pewaris telah melakukan kejahatan yang diancam dengan hukuman lima (5) tahun penjara atau hukuman yang lebih berat. 
Dari pasal ini terlihat adanya perubahan yang mendasar jika dibandingkan dengan dasar hukum kewarisan sebagaimana ditentukan dalam Al-Qur'an atau hadits. Hal ini juga yang juga menjadi rujukan dalam Kompilasi Hukum Islam (KHI) dalam memberikan batasan tentang hal atau apa saja yang dapat menghalangi hak kewarisan seseorang. Demikian halnya dengan kitan-kitab hukum Islam yang membahas tentang kewarisan dan buku-buku hasil karya ahli fiqih di Indonesia, mereka juga tidak menyertakan aspek perbuatan percobaan pembunuhan ini menjadi unsur bagi terhalangnya hak waris seseorang.

Dengan melihat kepada ketentuan Pasal $173 \mathrm{KHI}$ mengenai terhalangnya kewarisan, betapa pasal ini sekilas dipengaruhi oleh ketentuan hukum yang terdapat dalam Hukum Positif. KHI yang oleh sebagian kalangan disebut sebagai fiqih ala Indonesia, juga belum bisa diberlakukan secara utuh dan mutlak karena masih terdapat hal-hal yang baru dan menyimpang. Dengan demikian keberadaan $\mathrm{KHI}$ sebagai sebuah kodifikasi hukum Islam untuk masyarakat Indonesia belum final. Hal dikarenakan $\mathrm{KHI}$ adalah hasil pemikiran dan karya karya manusia yang di dalamnya tetap berpotensi menyimpan beberapa kekurangan. Namun begitu uraian yang apresiatif juga perlu untuk diberikan kepada $\mathrm{KHI}$ ini, dimana terlepas dari kekuarangan yang terdapat di dalamnya dan masih perlunya untuk dilakukan pembenahan, $\mathrm{KHI}$ juga telah menyerap nilai hukum yang hidup dan berlaku di Indonesia.

Secara umum bisa dikatakan bahwa ketentuan materi mengenai masalah hukum kewarisan yang diatur dalam $\mathrm{KHI}$ secara garis besar tetap berpedoman kepada garis-gars besar ketentuan hukum yang terdapat dalam faraid. Di dalamnya menunjukkan warna alam pikiran asas 'qathi' yang dominan dalam perumusannya, sehingga hampir keseluruhannya berpedoman kepada garis rumusan nash-nash yang terdapat dalam Al-Qur'an. ${ }^{21}$

Namun juga di dalam ketentuan Pasal 173 $\mathrm{KHI}$ diatur tentang terhalangnya seseorang

21 M. Yahya Harahap, 1992, "Informasi Materi Kompilasi Hukum Islam" dalam Mimbar Hukum No. 5 tahun III, Al-Hikamh \& Direktorat Pebnaan Badan Peradilan Agama, Jakarta, h. 53. untuk menjadi ahli waris yang pada dasarnya hanya berupa melakukan tindakan kejahatan terhadap pewarisnya. Tapi di dalam pasal ini tidak mencantumkan bahwa beda agama dan perbudakan menjadi penghalang utama untuk menjadi ahli waris sebagaimana hal ini diatur dalam ketentuan Hukum Islam.

Dalam ketentuan pidana Islam, sanksi hukuman terhadap percobaan pembunuhan adalah hukuma ta'zir. Adapun sanksi ta'zir ini tidak ada ketentuan untuk bobot dan ukurannya dimana hal ini lebih ditentukan berdasarkan ijtihad dari pihak hakim yang menangani kasus jarimah tersebut. Dalam Hukum Islam, wujud nyata dari hukuman ta'zir ini bervariasi yaitu bisa berupa bentakan (peringatan keras), hukuman penjara, dicambuk, atau diasingkan dari wilayahnya. ${ }^{22}$ Walaupun tidak terdapat ketentuan ukurannya namun bukan berarti hukuman ta'zir ini dianggap sebagai hukuman yang ringan.

Dalam perspektif prinsip hukum, percobaan pembunuhan menurut ketentuan Hukum Islam tidak ditempatkan sebagai tindakan pembunuhan itu sendiri. Sehingga tindakan ini (percobaan pembunuhan) dianggap sebagai tindak kejahatan yang belum selesai yang mengandung konsekuensi hukum yang berbeda dengan tindak pidana/ jarimah pembunuhan yang telah selesai. Dari prinsip ini maka ada alasan untuk menyatakan bahwa pelaku percobaan pembunuhan masih berhak terhadap hak kewarisan, karena pada prinsip hukumnya ketentuan hukuman yang dijatuhkan terhadap pelaku jarimah percobaan pembunuhan berbeda sama sekali dengan ketentuan hukuman yang dijatuhkan terhadap pelaku jarimah pembunuhan.

Kemudian dari perspektif produk hukum, jelas disebutkan bahwa dalam Hukum Islam sebabsebab terhalangnya kewarisan adalah hal-hal yang telah diuraikan di depan, dan di dalamnya tidak terdapat sebab/unsur melakukan tindakan percobaan pembunuhan sebagai unsur yang menghilangkan hak waris seseorang. Di pihak lain, KHI dalam Pasal 173 secara gamblang menyatakan bahwa pelaku pembunuhan dapat terhalangi haknya untuk mendapat warisan. Tentu jika hal ini dipahami dalam konteks permukaan

22 Wahbah Azzuhaili, 1989, Al-Fiqh al Islam wa 'Adillatuhu, Dar al Fikr, Damaskus, h. 207. 
akan menghadapkan kepada dualisme antara dua produk hukum yang keduanya sama-sama berada dalam ketentuan ajaran yang sama yaitu ajaran Islam.

Dimungkinkan sekali hal utama yang dijadikan pertimbangan $\mathrm{KHI}$ menempatkan unsur percobaan pembunuhan sebagai hal yang menyebabkan terhalangnya hak waris seseorang disandarkan kepada pertimbangan suasana hukum yang berlangsung dalam masyarakat Indonesia. Meskipun mayoritas penduduk Indonesia adalah Muslim, namun sebuah fakta hukum menunjukkan pengaruh Hukum Islam dalam masyarakat hukum Indonesia tidak berlangsung secara sepenuhnya. Ini dikarenakan secara konstitusional bentuk negara Indonesia bukan negara agama (Islam) melainkan sebagai negara sekuler yang di dalamnya hidup prinsip-prinsip religiusitas (agama). Keadaan yang demikian ini yang membuat produk hukum lain yang dalam hal ini adalah Hukum Positif, juga Hukum Adat, memiliki tempat dan pengaruh yang cukup kuat dalam masyarakat hukum Indonesia.

Dalam menyikapi keadaan yang demikian ini, sangat tidak mungkin jika menyandarkan atau berusaha mencari mana yang paling benar dan tepat dari masing-masing ketentuan hukum yang ada dengan berdasar kepada ketentuan formal yang tertulis dalam ketentuan hukum atau pasalnya. Jika hal ini yang dilakukan maka yang dimungkinkan adalah terjadinya penyalahan terhadap ketentuan yang termaktub dalam Pasal $173 \mathrm{KHI}$ karena dinilai bertentangan atau tidak sama dengan ketentuan/prinsip hukum yang terdapat dalm Hukum Islam. Atau sebaliknya, Hukum Islam bisa dipandang atau dinilai kaku atau kurang lentur dalam menerapkan prinsip dan ketentuannya, dengan tanpa memperhatikan realitas atau kenyataan hukum yang hidup dalam masyarakat (Indonesia).

Menurut hemat penulis, apa yang telah menjadi ketentuan dalam Pasal $173 \mathrm{KHI}$ tentang terhalangnya hak kewarisan merupakan sebuah produk hukum yang sudah maksimal dalam konteks masyarakat Islam Indonesia saat ini, meski hal ini bukan berarti tidak menutup kemungkinan terjadi penyesuaian di masa-masa mendatang paralel dengan dinamika dan perkembangan nilai dan prinsip hukum yang senantiasa berlangsung.
Bagaimanapun juga penempatan ketentuan Pasal 173 itu juga dilakukan setelah melewati serangkaian proses yang melibatkan pemikiran para fuqaha dan ahli hukum Islam di Indonesia, dan bisa dipastikan dalam memutuskan ketentuan itu mereka tidak mengabaikan sama sekali kenyataan hukum yang hidup, dihayati, dan dipraktekkan dalam masyarakat, dan sekaligus juga mereka tidak menelan mentah-mentah dan apa adanya ketentuan yang digariskan dalam Hukum Islam. Hal ini dikarenakan Hukum Islam akan sepenuhnya dilaksanakan ketika sistem kenegaraan dan masyarakat benar-benar sebagai negara Islam. Keadaan ini yang tidak terjadi di negara Indonesia. Hukum adalah refleksi sosiolegal masyarakat untuk menata kehidupan. Dalam Islam, hukum adalah sebagai hasil pergumulan dialektis antara konteks, teks dan subyek dalam bingkai yang sangat teologis. Dengan kata lain, hukum sebagai pelembagaan nilai-nilai yang inheren dalam teks-teks suci, realitas, dan kepribadian para ulama. Dalam arti ini hukum selalu memiliki basis sosial kulturalideologis.

Ketentuan Pasal $173 \mathrm{KHI}$ ini bisa diajukan sebagai realisasi dari prinsip dalam Hukum Islam tentang diserahkannya sebuah ketentuan hukum yang berlaku atau akan diberlakukan kepada pihak ulil amri atau hakim dalam menentukan hukuman ta'zir atas tindakan pidana (jarimah).

Ketentuan yang dihasilkan ulil amri atau hakim itu diwujudkan ke kepada suatu peraturan dalam bentuk pasal hukum dalam wujud perundangan yang lahir karena keputusan peradilan (yurisprudensi) dan ketentuan hukum, yang dalam hal ini adalah ketentuan pasal tentang terhalangnya hak kewarisan seseorang karena alasan tindak pidana percobaan pembunuhan.

\section{KESIMPULAN}

1. Percobaan adalah usaha mencoba sesuatu atau usaha hendak berbuat sesuatu, akan tetapi tidak sampai kepada sesuatu tujuan atau maksud. Percoabaan pidana atau jarimah dalam terminologi teknis-yuridis Hukum Islam. Dalam teknis yuridis yang terdapat Hukum Islam dan menjadi pembicaraan di kalangan fuqaha adalah tentang pemisahan antara jarimah (pidana) yang telah selesai dan jarimah 
yang belum selesai.

2. Pintu masuk terhadap dimungkinkannya pidana percobaan pembunuhan sebagai unsur yang bisa menjadi penghalang hak kewarisan Islam adalah pada penerapan hukum ta'zir yang keberadaannya ditujukan untuk memberikan sanksi hukum terhadap tindak pidana belum selesai. Dari pemikiran ini, reaktualisasi Hukum Islam yang menyatakan tindak pidana percobaan menjadi sebab terhalangnya hak kewarisan mendapat sandaran argumentasi. Hal yang dijadikan pertimbangan $\mathrm{KHI}$ menempatkan percobaan pembunuhan sebagai penyebab terhalangnya hak waris juga disandarkan pada pertimbangan suasana hukum dalam masyarakat Indonesia. Dan secara prinsip hukum ketentuan KHI itu tidak 'bertentangan' dengan Hukum Islam, karena dalam Hukum Islam setiap jarimah baik yang telah selesai dan jarimah yang belum selesai, di antaranya tindakan jarimah percobaan pembunuhan, memiliki konsekuensi terhadap jatuhnya sanksi hukum. Kedua produk hukum tersebutsecara prinsip adalah sama yaitu berketetapan dalam memberikan sanksi hukum terhadap semua perbuatan yang melanggar.

\section{DAFTAR PUSTAKA}

Ahmad Rofiq, 1993, Fiqih Mawaris, RajaGrafindo Persada, Jakarta,

Abdurahman, 1992, Kompilasi Hukum Islam, Akademika Pressindo, Jakarta

ADjazuli, 1997, Fiqh Jinayah: Upaya Menanggulangi Kejahatan dalam Islam, PT RajaGrafindo Persada, Jakarta

Suparman Usman, 1993, Ikhtisar Hukum Waris menurut KUHP, Dar al Ulum Press, tt., Imam al-Bukhari, 1971/1401 H, Shahih al-Bukhari, Juz 8, Dar al-Fikr, Beirut Hadits Riwayat Bukhari dari Ibnu Abbas

M. Yahya Harahap, “Materi Kompilassi Hukum Islam” dalam Mahfud MD dkk., 1993, Peradilan Agama dan Kompilasi Hukum Islam dala Tata Hukum Indonesia, UII Press, Yogyakarta, M YahyaHarahap., 1990, Kedudukan, Kewenangan danAcara Peradilan Agama UU No 7 Th 1989, PustakaKartini, Jakarta

Wahbah Azzuhaili, 1989, Al-Figh al Islam wa 'Adillatuhu, Dar al Fikr, Damaskus

Suparman Usman, 1993, Ikhtisar Hukum Waris Menurut Kitab Undang-UndangHukum

Perdata (Burgerlijk Wetboek), Darul Ulum Press, Serang

Haliman, 1973, Hukum Pidana Syariat Islam, PT Bulan Bintang, Jakarta

Al-Baihaqi, 1354 H, Assunah al_Kubra Juz 8 Bab Ma Ja-a fi at;Ta'zir, Dar as-Sadir, Beirut

M. Yahya Harahap, 1992, “Informasi Materi Kompilasi Hukum Islam” dalam Mimbar Hukum

No. 5 tahun III, Al-Hikamh \& Direktorat Pebnaan Badan Peradilan Agama, Jakarta,

R. Sugandi, 1989, KUHP dan Penjelasannya, Usaha Nasional, Jakarta

Marsum, 1991, Jinayat: Hukum Pidana Islam, Fakultas Hukum UII, Yogyakarta

Ronny Hanitijo Soemitro, 1994, Metodologi Penelitian Hukum dan Jurimetri, Ghalia Indonesia, Jakarta

Lexy J Moloeng, 1997, Metode Penelitian Kualitatif, Remaja Rosda Karya, Bandung

Suharsimi Arikunto, 1993, Prosedur Penelitian Suatu Pendekatan Praktek, Rineka Cipta, Jakarta

Klaus Krippendorf, 1993, Analisis Isi Pengantar Teori dan Metodologi, RajaGrafindo Persada, Jakarta 